\title{
Factors Affecting Youth Smoking Behavior In High School Pgri 4 Banjarmasin
}

\author{
Esti Yuandari, Dini Rahmayani, R. Topan Aditya Rahman \\ Email: yuandariesti@gmail.com \\ Sari Mulia University
}

\begin{abstract}
Smoking behavior is an activity that is carried out by many people and becomes a trend especially among adolescents but can be bad for health. Today more and more young people are exposed to cigarette smoke and unwittingly continue to accumulate these toxic and carcinogenic substances. The purpose of this study was to determine whether there was influence of knowledge, attitudes, parents and friends about smoking behavior towards adolescents. This study was an observational analytic study with a Cross Sectional approach, with a total sample of 184 people. The average smoking behavior of high school students PGRI 4 Banjarmasin is in the heavy category as many as 104 people $(56.5 \%)$. Based on the results of the analysis it can be concluded that there is a relationship between knowledge and attitude with smoking behavior of adolescents
\end{abstract}

Key Word: Factors, Behavior, Smoking, Adolescents

\section{Introduction}

Smoking is a habit that is difficult to stop, and has a negative impact on the smoker and the people around him. In the beginning, people smoked tobacco using pipes. 1840 was known as cigarettes, but had not had an impact on tobacco marketing. In 1881 there was a massive cigarette production with the help of machines. Through cigarette advertisements became famous and in 1920 had spread throughout the world. In the decades before the 1960s there was strong evidence that tobacco use was associated with several diseases.[1]

Smoking is a behavior that burns tobacco products that are intended to be burned, smoked and inhaled including kretek cigarettes, white cigarettes, cigars or other forms produced from the nicotina tabacum, nicotina rustica and other species or synthetic species whose smoke contains nicotine and tar, with or without additives. [2]

The content of cigarettes makes it easy for a person to stop smoking for two reasons, namely the addiction to addiction to nicotine and the psychological feel of losing a certain activity if you stop smoking. [3] Smoking is one of the longstanding negative human habits. This habit is often difficult to stop because of the dependency effects caused by the substances contained, the effects of which are in the form of a disease that can occur in a long time, so that it often causes failure in efforts to prevent not smoking or stop smoking. [4]

According to Fattah in Alamsyah (2017) Smoking behavior is an activity that is widely carried out by many people and is a trend especially among adolescents but can be bad for health. Smoking habits in school-aged children in Indonesia are often seen in high school students because at this age is a transition between childhood and adulthood. [5] Adolescence is a crucial period because at this time children experience many changes in their 
psychological and physical aspects. Psychiatric changes cause confusion among adolescents, so they experience emotional turmoil and mental stress that easily deviates from social rules and norms prevailing in society.

Many occur in the community environment that we can not deny that smoking behavior has begun at the age of children and adolescents. Smoking behavior of the population 15 years and over has not yet decreased from 2007 to 2013, tending to increase from $34.2 \%$ in 2007 to $36.3 \%$ in 2013. Found 1.4 percent of smokers aged 10-14 years [6]. The percentage of southern Kalimantan population aged 10 years and over who smokers every day tends to increase with increasing age, at the age of 10-14 years has reached $0.7 \%$. The age of 10 years and over the population of South Kalimantan Province first smoked every day at the highest age of $15-19$ years $(36.8 \%)$. [7]

Smoking behavior in adolescents generally increases according to the stage of development which is characterized by an increase in the frequency and intensity of smoking and often results in them experiencing nicotine dependence [8]. If teens continue to smoke cigarettes, nicotine buildup will occur in the brain. The accumulation of nicotine in the brain can cause harm to health, starting to decrease motivation, decreased concentration ability and memory.

Adolescent smokers and the younger ages begin to smoke a separate concern because it brings real long-term consequences in the form of the negative impact of smoking on health. There are thousands of articles proving a causal relationship between the use of cigarettes with the occurrence of various cancers, heart disease, respiratory system diseases, reproductive disorders and pregnancy. This is not surprising because tobacco smoke contains more than 4000 toxic substances and 43 cancer-causing substances (carcinogenic). Today more and more young people are exposed to cigarette smoke and continue to unwittingly accumulate these toxic and carcinogenic substances. [9]

Factors that influence smoking behavior in adolescents include predisposing factors, reinforcing factors and enabling / enabling factors. These factors can influence smoking behavior in adolescents because adolescence is a period that is prone to negative influences. Teenagers are more imitating what they see or hear from others. At this time adolescents face conflicts about what they see and what they perceive about the ideal body structure. [10]

Increasing levels of cigarette use among adolescents as well as effects or effects on health then one of the most important strategies is how to prevent teens from becoming smokers or addictions that do not stop and it is important to know what factors are causing teens to become cigarette users

\section{Material And Method}

The design of this study was an observational analytic study with a Cross Sectional approach that aims to determine whether there is an influence of knowledge, attitudes, parents and friends about smoking behavior in adolescents. This research is quantitative. The population in this study were all male teenage students totaling 184 people with a sampling technique using total sampling.

\section{Result}




\subsection{Age Distribution}

Table 1. Age Distribution

\begin{tabular}{c|c|c}
\multicolumn{3}{c}{ Table 1. Age Distribution } \\
\hline Age & y & Frequenc \\
& & \\
\hline $14^{\text {th }}$ & 65 & 35,3 \\
\hline $15^{\text {th }}$ & 20 & 10,9 \\
\hline $16^{\text {th }}$ & 99 & 53,8 \\
\hline Total & 184 & 100 \\
\hline
\end{tabular}

From the table above shows the characteristics of respondents by age can be seen that the average age of respondents is 16 years as many as 199 people $(53.8 \%)$.

\subsection{Distribution of Smoking Behavior}

Table 2. Distribution of Smoking Behavior

\begin{tabular}{c|c|c}
\hline Behavior & Frequency & $\%$ \\
\hline Weight $(>10$ stick/day) & 104 & 56,5 \\
\hline Light $(\leq 10$ stick/day & 80 & 43,5 \\
\hline Total & 184 & 100
\end{tabular}

From the table above shows the characteristics of respondents based on smoking behavior can be seen that the average smoking behavior of respondents is in the weight category of 104 people $(56.5 \%)$

\subsection{Distribution of respondents' knowledge about the dangers of smoking}

Table 3. Distribution of respondents' knowledge about the dangers of smoking:

\begin{tabular}{l|l|l}
\hline Knowledge & Frequency & $\%$ \\
\hline Not Good & 155 & 84,2 \\
\hline Good & 29 & 15,8 \\
\hline Total & 184 & 100
\end{tabular}

From the table above shows the characteristics of respondents based on the knowledge of respondents about the dangers of smoking can be seen that the average knowledge of respondents is in the category of less than good as many as 155 people $(84.2 \%)$.

\subsection{Distribution of adolescent attitudes about smoking behavior}

Table 4. Distribution of adolescent attitudes about smoking behavior

\begin{tabular}{c|l|c}
\hline Attitude & Frequency & $\%$ \\
\hline Negatif & 170 & 92,4 \\
\hline Postif & 14 & 7,6 \\
\hline Total & 184 & 100 \\
\hline
\end{tabular}


From the table above shows the characteristics of respondents based on respondents' attitudes about smoking behavior can be seen that the average attitude of respondents is negative that is as many as 170 people $(92.4 \%)$

\subsection{Relationship between Age and Smoking Behavior}

Table 5. Relationship between Age and Smoking Behavior

\begin{tabular}{c|c|c|c|c}
\hline \multirow{2}{*}{ Age } & \multicolumn{2}{|c|}{ Smoking Behavior } & Total & \multirow{2}{*}{ P value } \\
\cline { 2 - 3 } & Weight & Light & & \\
\hline 14 th & $28(26,9$ & $37(46,2)$ & $65(35,3)$ & \multirow{2}{*}{0,010} \\
\hline 15 th & $10(9,6)$ & $10(12,5)$ & $20(10,9)$ & \\
\hline 16th & $66(63,5)$ & $33(41,2)$ & $99(53,8)$ & \\
\hline Total & $104(100)$ & $80(100)$ & $184(100)$ & \\
\hline
\end{tabular}

Based on the results of the analysis found that the relationship between age and smoking behavior obtained $\mathrm{p}$ value of $0.010>0.05$. So it can be concluded that there is no relationship between age and smoking behavior.

3.6 Relationship between knowledge with smoking behavior

Table 6. Relationship between knowledge with smoking behavior

\begin{tabular}{l|c|c|c|c|c}
\hline \multirow{2}{*}{ Knowledge } & \multicolumn{2}{|c|}{ Smoking Behavior } & Total & $\begin{array}{l}\text { P value } \\
\text { (OR) }\end{array}$ & OR \\
\cline { 2 - 4 } & Weight & Weight & & \\
\hline Kurang Baik & $93(89,4)$ & $62(77,5)$ & $155(84,2)$ & \multirow{2}{*}{0,028} & 2,455 \\
\hline Baik & $11(10,6)$ & $18(22,5)$ & $29(15,8)$ & \\
\hline Total & $104(100)$ & $80(100)$ & $184(100)$ & & \\
\hline
\end{tabular}

Based on the results of the analysis between the relationship of adolescent knowledge about the dangers of smoking with smoking behavior, $\mathrm{p}$ value of $0.028<0.05$ with an OR value of 2.455. So it can be concluded that there is a relationship between adolescent knowledge about the dangers of smoking with smoking behavior, where adolescent knowledge that is not good has a 2.5 times chance as a heavy smoker.

\subsection{Relationship between attitude with smoking behavior}

\begin{tabular}{c|c|c|c|c}
\hline \multirow{2}{*}{ Attitude } & \multicolumn{2}{|c|}{ Table 7. Relationship between attitude with smoking behavior: } \\
\cline { 2 - 3 } & Weight & Total & $\begin{array}{l}\text { P value } \\
\text { (OR) }\end{array}$ \\
\hline Negatif & $100(96,2)$ & $70(87,5)$ & $170(92,4)$ & 0,028 \\
\hline Positif & $4(3,8)$ & $10(12,5)$ & $14(7,6)$ & $(3,571)$ \\
\hline
\end{tabular}




\begin{tabular}{c|c|c|c|c}
\hline Total & $104(100)$ & $80(100)$ & $184(100)$ & \\
\hline
\end{tabular}

Based on the results of the analysis between the relationship of adolescent attitudes with smoking behavior, $\mathrm{p}$ value of $0.028<0.05$ with an OR value of 3.571 . So it can be concluded that there is a relationship between adolescent attitudes with smoking behavior, where negative adolescent attitudes have an opportunity of 3.6 times as heavy smokers.

\section{Discussion}

\subsection{Teen Behavior}

Based on the results of research respondents' smoking behavior is in the weight category of 104 people (56.5\%), from 184 adolescents who were used as research samples. Adolescence is a period of transition from childhood to adulthood which is followed by various problems that exist because of physical, psychological and social changes. The transition period caused many difficulties in adjusting to himself and the social environment. Difficulties in adjusting have an impact on attitudes that emerge as a reflection of his personality that is still unstable. The desire to be recognized as an adult is often followed by imitating the habits of adults without being accompanied by mature thought. Though various choices taken during adolescence are important things that can have a direct impact on attitudes and behavior and have long consequences. The period of ambivalence of adolescents who are filled with a hesitant attitude when making a decision, encourages adolescents to tend to prefer friendships over choices for healthy living without cigarettes. His fear of the ignorance of his group's friends, makes teens want to look more existent by mixing to follow the habits of friends in their environment that is smoking, even though aware of the dangers it poses. In adolescence someone has a strong sense of attachment to the group.

The importance of being recognized in the group can also be another reason for the lack of influence of attitudes in suppressing smoking behavior among adolescents. The choice to be unkind or to disagree with various factors that are related to smoking can not be chosen because it was not able to defeat the pharmacological, social, and psychological factors that are needed. This means that in terms of pharmacological factors the effects of nicotine are controlling feelings and habits. Judging from social factors, the importance of feeling more accepted in a friend's environment and looking mature, and feeling more comfortable dominating more than choosing to be unkind to smoking. Judging from psychological factors, teen smokers believe that smoking can increase psychological comfort.

Based on Management of Affect Theory, there are four types of smoking behavior. First, smokers are influenced by positive feelings. They argue that by smoking someone will feel the addition of a positive taste. Green in Psychological Factor in Smooking added 3 sub types. 1) Pleasure relaxation, namely smoking behavior only to increase or increase the enjoyment that has been obtained, for example smoking after drinking coffee or eating. 2) Stimulation to pick them up, i.e. smoking behavior is only done modestly to please the feeling. 3) Pleasure of handling the cigarette, which is the pleasure obtained by holding a cigarette, is very specific to pipe smokers. Pipe smokers will spend time to fill the pipe with tobacco, while to smoke it only takes a few minutes. There are also smokers who prefer to linger to play cigarettes with their fingers long before he lit with fire. Second, smoking behavior that is influenced by negative feelings. Many people use cigarettes to reduce negative feelings, for example when you are angry, anxious, or anxious. Cigarettes are considered as saviors. They use cigarettes 
when bad feelings occur, so as to avoid feeling worse. Third, addictive smoking behavior. Green mentions psychological addiction (psychological addiction). Those who are addicted will tend to increase the dose of cigarettes used at any time after the effects of smoking are reduced. They generally will go out of the house to buy cigarettes, even though it is midnight, for fear of smoking is not available when he wants it. Fourth, smoking behavior that has become a habit. They use cigarettes at all not because of controlling feelings, but because it really has become a routine habit. It can be said of people of this type, smoking has become an automatic behavior, often without thinking and not realizing it. He revived his cigarette fire when the previous cigarette had been completely used up.

\subsection{Age With Smoking Behavior}

Characteristics of respondents by age can be seen that the average age of respondents is 16 years as many as 199 people $(53.8 \%)$. Based on the results of the analysis found that the relationship between age and smoking behavior obtained $p$ value of $0.010>0.05$. So it can be concluded that there is no relationship between age and smoking behavior. Behavior change is caused by the process of maturity, through the course of his age the more mature the individual concerned will adapt the behavior to the environment [11]. Green Theory, where age is a predisposing factor, this factor directly influences the occurrence of a person's behavior [12]. Age is the length of life calculated from birth. The more a person ages, the more responsiveness increases. The world of adolescent association that includes smoking as one of the builders of self-existence can lead to an attitude of indifference towards various things caused by smoking. This condition can arise because of the social environment that tends to be indifferent to various information about the dangers of smoking for the sake of recognition of himself to be accepted by his group. As a result of maintaining his existence in the social environment in his group can encourage intellectual change that is not mature. Yet at this age according to Piaget teenagers should get perfect intellectual development. Knowledge is the result of 'knowing' and occurs after the person senses a certain object. Most of human knowledge is obtained through the eyes and ears. The knowledge covered has six levels namely know, understand, application, analysis, synthesis and evaluation.

\subsection{Knowledge with Smoking Behavior}

Characteristics of respondents based on respondents' knowledge about the dangers of smoking can be seen that the average knowledge of respondents is in the unfavorable category of 155 people $(84.2 \%)$. While Based on the analysis of the relationship between the knowledge of adolescents about the dangers of smoking with smoking behavior, $\mathrm{p}$ value of $0.028<0.05$ with an OR value of 2.455 was obtained. So it can be concluded that there is a relationship between adolescent knowledge about the dangers of smoking with smoking behavior, where adolescent knowledge that is not good has a 2.5 times chance as a heavy smoker. Knowledge is one of the predisposing factors for the formation of a new behavior, to obtain sufficient knowledge about the dangers of smoking, it is necessary to have continuous and continuous information. Variable knowledge about the dangers of smoking on health and the substances contained in cigarettes are the dominant factors for smoking habits. For this reason, it is necessary to improve the level of knowledge for adolescents so that the level of smoking behavior becomes lower or even not smoking at all. The incessant advertising of the dangers of smoking on cigarette packs that have recently been implemented is hopefully to be one of the effective solutions in reducing cigarette addicts in adolescents in particular and in the general public. 


\subsection{Attitude with smoking behavior}

Of 184 adolescent attitudes of respondents about smoking behavior it can be seen that the average attitude of respondents is negative, as many as 170 people $(92.4 \%)$ and based on the results of the analysis between the relationship of adolescent attitudes with smoking behavior, $\mathrm{p}$ value of $0.028<0.05$ with OR value of 3.571 . So it can be concluded that there is a relationship between adolescent attitudes with smoking behavior, where negative adolescent attitudes have an opportunity of 3.6 times as heavy smokers. adolescents who have the habit of smoking with heavy categories are more often found in the group of adolescents who have negative attitudes as many as 170 people. Attitude is as a level of positive or negative tendencies associated with psychological objects, which include symbols, words, slogans, people, institutions, ideas and so on. Individuals are said to have a positive attitude towards a psychological object if they like it or have a favorable attitude, whereas individuals who are said to have a negative attitude towards psychological objects if they do not like it or their attitude is unfavorable towards psychological objects. Attitude on Green theory is one of the predisposing factors for the formation of a new behavior, to get a good attitude towards smoking behavior requires training on the dangers of smoking and how to deal with the effects of smoking specifically and there is always need to be refreshed. Therefore, to improve the attitude of respondents. which is still lacking in order to become good, requires regular health education

\section{Conclusion}

The relationship between age and smoking behavior obtained $\mathrm{p}$ value of $0.010>0.05$. So it can be concluded that there is no relationship between age and smoking behavior. The relationship of adolescent knowledge about the dangers of smoking with smoking behavior obtained $\mathrm{p}$ value of $0.028<0.05$ with an OR value of 2.455 . So it can be concluded that there is a relationship between adolescent knowledge about the dangers of smoking with smoking behavior, where adolescent knowledge that is not good has a 2.5 times chance as a heavy smoker. The relationship between adolescent attitudes with smoking behavior obtained $\mathrm{p}$ value of $0.028<0.05$ with an OR value of 3.571 . So it can be concluded that there is a relationship between adolescent attitudes with smoking behavior, where negative adolescent attitudes have an opportunity of 3.6 times as heavy smokers.

\section{References}

[1] Soetjiningsih. Tumbuh Kembang Remaja dan Permasalahannya. Jakarta : Sagung Seto. 2004

[2] Kemenkes. Peraturan Menteri Kesehatan Republik Indonesia Nomor 28 Tahun 2013 tentang Pencantuman Peringatan Kesehatan dan Informasi Kesehatan Pada Kemasan Produk Tembakau. Jakarta : Kemenkes RI. , 2013.

[3] Aula, Lisa Ellizabet. Stop Merokok. Jogjakarta : Garai Ilmu. 2010.

[4] Adioetomo, S. M. Meredam Wabah: Pemerintah Dan Aspek Ekonomi Terhadap Tembakau. Publikasi Bank Dunia. 2000.

[5] Alamsyah Agus dan Nopianto. Determinan Perilaku Merokok Pada Remaja. DOI:http://doi.org/10.22216/jen.v2il.1372. 2017. 
[6] Riskesdas. Laporan Nasional 2013. Jakarta: Badan Penelitian dan Pengembangan Kesehatan Kemenkes RI Tahun 2013. 2013.

[7] Riskesdas. Laporan Nasional 2009. Provinsi Kalimantan Selatan : Badan Penelitian dan Pengembangan Kesehatan Kemenkes RI Tahun 2009. 2009.

[8] Mukuan. Hubungan Antara Pengetahuan Dan Sikap Tentang Bahaya Merokok Bagi Kesehatan Dengan Tindakan Merokok Pelajar SMK Kristen Kawangkoan. 2012.

[9] Depkes, 2011. Lindungi Generasi Muda Dari Bahaya Merokok. http://www.depkes.go.id/article/print/1528/lindungi-generasi-muda-dari-bahayamerokok.html. Di akses 6 Maret 2018

[10] Wong, Donna L, dkk. Buku Ajar Keperawatan Pediatrik. Volume 1. Edisi 6. Jakarta: EGC. 2009

[11] Notoatmodjo, Soekidjo. Promosi Kesehatan dan Perilaku Kesehatan. Jakarta: Rineka cipta. 2007.

[12] Green. Perilaku remaja. Jogjakarta: Pustaka Pelajar. (2010).

[13] Gunarsa. Psikologi perkembangan anak, remaja dan keluarga. Jakarta: PT. Gunung Mulia. (2011). 
